\title{
STATs in NK-Cells: The Good, the Bad, and the Ugly
}

\author{
Dagmar Gotthardt ${ }^{\dagger}$ and Veronika SexI*
}

Department for Biomedical Sciences, Institute of Pharmacology and Toxicology, University of Veterinary Medicine, Vienna, Austria

Natural killer (NK)-cells are major players in the fight against viral infections and transformed cells, but there is increasing evidence attributing a disease-promoting role to NK-cells. Cytokines present in the tumor microenvironment shape NK-cell maturation, function, and effector responses. Many cytokines signal via the Janus kinase (JAK)signal transducer and activator of transcription (STAT) pathway that is also frequently altered and constitutively active in a broad range of tumor cells. As a consequence, there are currently major efforts to develop therapeutic strategies to target this pathway. Therefore, it is of utmost importance to understand the role and contributions of JAKSTAT molecules in NK-cell biology - only this knowledge will allow us to predict effects of JAK-STAT inhibition for NK-cell functions and to successfully apply precision medicine. We will review the current knowledge on the role of JAK-STAT signaling for NK-cell functions and discuss conditions involved in the switch from NK-cell tumor surveillance to disease promotion.

Keywords: JAK-STAT, tumor surveillance, cytotoxicity, immunologic, mouse models, NK cells, VEGF-A, tumor promotion

\section{INTRODUCTION}

Natural killer (NK) cells are major players of the innate immune system and immediate effector cells against viral infections, pathogens, and malignant cells. In humans, NK-cells compromise 5-15\% of circulating blood lymphocytes and are further sub-divided based on the expression of the cell adhesion molecule CD56 and the low affinity Fc-receptor CD16 into CD3-CD56 ${ }^{\text {bright }} \mathrm{CD} 16^{-}$and $\mathrm{CD}^{-}{ }^{-} \mathrm{CD} 56^{\mathrm{dim}} \mathrm{CD} 16^{+} \mathrm{NK}$-cells. CD56 ${ }^{\text {bright }}$ NK-cells are mainly found in lymph nodes, produce cytokines upon activation, and possess only minor cytotoxic potential. Upon maturation to CD56 ${ }^{\mathrm{dim}}$ cells-the majority of circulating NK-cells in healthy humans representing approximately $90 \%$ of NK-cells-gain significant cytotoxic potential $(1,2)$. There is ample evidence for the ability of NK-cells to recognize and lyse a broad variety of tumor cells (3-5). The ability of NK-cell-mediated immune surveillance extends to the prevention of metastatic spread (6-8), which is currently one of the dominating clinical problems in cancer therapy.

Initially described to function without prior sensitization, accumulating evidence demonstrates that NK-cell effector function is a complex and tightly regulated process (9-12). This ensures rapid effector reactions while preventing autoimmunity (13). During development, NK-cells undergo a licensing process that shapes their responsive steady state. NK-cells lacking inhibitory receptors or unable to recognize cognate MHC molecules maintain a hyporesponsive state $(13,14)$. Even if fully developed and equipped to act against target cells, NK-cells require a costimulatory signal to pull 
the final trigger. Cytokines provided by the microenvironment or the ligation of activating receptors serve as promoting signals $(15,16)$. NK-cell activation is thus also controlled by the availability of cytokines including type I interferons (IFNs) from TLR ${ }^{+}$ cells. IFNAR signaling in dendritic cells leads to the subsequent production of IL-15 that is trans-presented to activate NK-cells (17). Besides IL-15, also IL-2 produced by $\mathrm{CD} 4^{+} \mathrm{T}$ cells stimulates NK-cell activation while regulatory T cells $\left(\mathrm{T}_{\text {regs }}\right)$ inhibit NK-cell responses in a TGF- $\beta$-dependent manner. Moreover, $\mathrm{T}_{\text {regs }}$ expressing the high affinity IL-2 receptor alpha chain CD25 limit the availability of IL-2 for NK-cells $(18,19)$.

Another layer of complexity is added by the escape mechanisms of tumor cells. Tumor cells evade NK-cell recognition by several mechanisms including changes in expression of MHC class I or secretion of cytokines and mediators impeding NK-cell responses (20). Immunosuppressive cytokines such as TGF- $\beta$ or adenosine in the tumor microenvironment block NK-cell maturation and their cytotoxic potential or act indirectly by recruiting suppressor cells $(21,22)$. Cytokines have thus both abilities; they may activate or block NK-cells.

Most cytokines influencing NK-cell functions signal via Janus kinase (JAK)-signal transducer and activator of transcription (STAT) pathway, a conserved pathway transmitting extracellular signals from the cell surface to the nucleus (23). The JAK-STAT pathway is frequently altered and constitutively active in a broad range of tumors. There are major efforts to develop therapeutic strategies to target components of this pathway (24-26). It is thus critical to comprehend the role of JAK-STAT molecules in NK-cell biology. This knowledge will enable to predict effects of JAK-STAT inhibition for NK-cells, a prerequisite for precision medicine.

\section{JAK-STAT}

Cytokine binding to a respective receptor on the cell surface leads to the activation of receptor-associated tyrosine kinases, the JAKs. Once activated, JAKs trans-phosphorylate each other, thereby creating docking sites for signal transducer and activator of transcription (STAT) molecules. Subsequent to binding, STATs become activated by JAK-mediated tyrosine phosphorylation and form homo- or heterodimers, translocate to the nucleus where they regulate transcription $(27,28)$. Four distinct JAK kinases (JAK1, 2, 3, and TYK2) as well as seven different STAT proteins exist (STAT1, 2, 3, 4, 5A, 5B, and 6). One cytokine may activate more than one member of the JAK and/or STAT family (29). Table 1 summarizes our current knowledge on JAK-STAT signaling in NK-cells.

\section{JAKs: THE DRIVER OF THE STATS}

One cytokine may activate more than one JAK and each JAK targets more than one STAT protein. This multilayered and complex activation pattern creates sometimes elaborate phenotypes upon deletion or inhibition of single components (46). The distinct roles of JAK kinases for NK-cell biology are on the edge of being unraveled, currently only limited information is available.
Treatment with the JAK1/JAK2 inhibitor ruxolitinib reduces NK-cell numbers, impairs their proliferation, maturation, and cytolytic capacity. Application of ruxolitinib in a murine breast cancer model enhanced metastatic spread by interfering with NK-cell functions $(7,47)$. The fact that ruxolitinib efficiently inhibits JAK1 and JAK2 but also with low affinity JAK3, makes it difficult to assign specific roles to distinct members of the JAK family. NK-cells fail to develop in $J a k 3^{-/-}$mice-a phenotype that is mirrored in patients harboring Jak3 mutations. These patients suffer from a SCID phenotype lacking T and NK-cells (48-50). The contribution of JAK1 and JAK2 on NK-cell development and function needs to be further explored. While JAK3 is predominantly expressed in the hematopoietic compartment, JAK1 and JAK2 are ubiquitously expressed and Jak1 and Jak2 knockouts are perinatal/embryonic lethal $(51,52)$. JAK1 has been reported to be crucial for lymphopoiesis, and both JAK1 and JAK3 are important upstream kinases mediating IL-15-dependent signaling and subsequent STAT5 activation (52-54). It is attractive to speculate that loss of JAK1 would as well induce the loss of peripheral NK-cells.

Experiments using Jak2- conditional knockout mice uncovered a critical role for JAK2 in NK-cell maturation (7). Breast cancer metastasis related to impaired NK-cell function was enhanced in mice treated with the JAK2-specific inhibitor BSK805. Simultaneous treatment with IL-15 prevented the enhanced metastasis provoked by JAK2 inhibition. This indicates that BSK805-mediated JAK2 inhibition does not affect IL-15mediated responses in NK-cells presumably acting via JAK1 and JAK3 (7). Only the generation and analysis of NK cell-specific conditional knockout mice will allow us to characterize the individual effects of JAKs on NK-cell development and effector function.

In contrast to other JAKs, Tyk2-/- NK-cells are present at normal numbers but show impaired IL-12/IL-18-mediated signaling with reduced STAT4 activation. Consequently, Tyk2-/- NK-cells possess a severely impaired cytolytic activity, do not efficiently clear certain infections, and display an impaired tumor immune surveillance (55-58). In line, patients with autosomal recessive Tyk2 mutations suffer from recurrent bacterial and viral infections and display impaired NK-cell responses (59).

\section{THE GOOD: STAT1: IT TURNS THE KILLING ON}

STAT1 and STAT2 are well studied transcription factors and important for signals in response to IFNs (60). Our knowledge on STAT2-regulated NK-cell functions is limited; it is known that STAT2 controls viral load during LCMV infections (61). In contrast, STAT1 effects have been characterized in more detail. STAT1 is a crucial regulator of IFN- $\gamma$ production and NK-cell cytotoxicity (60-62). Stat1-deficient mice are highly susceptible to bacterial and viral infections. Stat $1^{-/}$mice show reduced expression of MHC class I molecules, which is thought to lead to hyporesponsive, unlicensed NK-cells $(63,64)$. It is currently unclear whether theimpaired cytotoxicity is solely the consequence of the impaired licensing or whether STAT1 fulfills other major 
TABLE 1 | Janus kinase (JAK)/signal transducer and activator of transcription (STAT) signaling in natural killer (NK)-cells (27, 30-45).

\begin{tabular}{|c|c|c|c|c|}
\hline Cytokine & $\begin{array}{l}\text { Receptor-associated } \\
\text { JAKs }\end{array}$ & Activated STATs & Function & Effect induced by \\
\hline IL-2 & $\begin{array}{l}\text { JAK1, JAK3 } \\
\text { JAK2 }\end{array}$ & $\begin{array}{l}\text { STAT1, STAT3, STAT5 } \\
\text { STAT4 }\end{array}$ & $\begin{array}{l}\text { Proliferation } \\
\text { Activation }\end{array}$ & $\begin{array}{l}\text { STAT5 } \\
\text { STAT1/4/5; STAT3? }\end{array}$ \\
\hline IL-7 & JAK1, JAK3 & STAT5 & $\begin{array}{l}\text { Survival of CD56 bright NK-cells, upregulation of FasL } \\
\text { Development of distinct NK-cell subsets }\end{array}$ & STAT5 \\
\hline IL-12 & JAK2, TYK2 & STAT1, STAT3, STAT4 & $\begin{array}{l}\text { Activation } \\
\text { Induction of Vegf-A expression }\end{array}$ & $\begin{array}{l}\text { STAT1/4 } \\
\text { STAT3? }\end{array}$ \\
\hline $\mathrm{IL}-15$ & JAK1, JAK3 & $\begin{array}{l}\text { STAT5 } \\
\text { STAT3 }\end{array}$ & $\begin{array}{l}\text { Survival, maturation, proliferation } \\
\text { Activation }\end{array}$ & $\begin{array}{l}\text { STAT5 } \\
\text { STAT5, STAT3? }\end{array}$ \\
\hline IL-10 & JAK1 & STAT3 & $\begin{array}{l}\text { Activation } \\
\text { Induction of Vegf-A expression }\end{array}$ & $\begin{array}{l}\text { STAT3 } \\
\text { STAT3? }\end{array}$ \\
\hline $\mathrm{IL}-21$ & JAK1, JAK3 & STAT1, STAT3 & $\begin{array}{l}\text { Antiproliferative (mouse NK-cells), proliferation (human NK-cells) } \\
\text { Maturation, activation } \\
\text { Induction of Vegf-A expression }\end{array}$ & $\begin{array}{l}\text { STAT3? } \\
\text { STAT1? } \\
\text { STAT3? }\end{array}$ \\
\hline $\mathrm{IL}-27$ & JAK1 & STAT1, STAT3, STAT5 & $\begin{array}{l}\text { Activation } \\
\text { Increased ADCC } \\
\text { Increased IL-10 production } \\
\text { Increased viability } \\
\text { Decreased proliferation }\end{array}$ & $\begin{array}{l}\text { Unknown } \\
\text { STAT5? } \\
\text { STAT3? } \\
\text { STAT5? } \\
\text { STAT3? }\end{array}$ \\
\hline Interferon- $\alpha / \beta$ & JAK1, TYK2 & STAT1, STAT3 & $\begin{array}{l}\text { Maturation } \\
\text { Activation } \\
\text { Induction of Vegf-A expression }\end{array}$ & $\begin{array}{l}\text { STAT1; STAT4? } \\
\text { STAT } 1 / 3 / 4 \\
\text { STAT3? }\end{array}$ \\
\hline
\end{tabular}

functions. The complexity of STAT1 signaling in innate immunity is further highlighted by the existence of a non-canonical STAT1 pathway. STAT1 ${ }^{\mathrm{Y} 701 \mathrm{~F}}$ mutant proteins that cannot be activated by JAKs in the canonical manner partially rescue impaired cytolytic responses of Stat1 ${ }^{-/}$NK-cells. One potential explanation for this unexpected phenomenon is the finding that STAT1 locates to the immunological synapse when NK-cells conjugate target cells. In line, STAT1 has been shown to bind proteins involved in cell junction formation at the immunological synapse during tumor cell recognition (65). Moreover, ex vivo derived NK-cells show a constitutive phosphorylation of the STAT1-S727 residue restraining NK-cell cytotoxicity. This phosphorylation is present without any stimulus and prior to tyrosine phosphorylation, thus deviating from the canonical STAT activation $(6,28)$. These observations point at a complex and multilayered function of STAT1 in NK-cells and suggest STAT1 as a central node integrating several processes.

Many effects described in Stat1-deficient mice are mirrored in patients. STAT1 deficiency in humans is an autosomal recessive immune disorder; null mutations are associated with recurrent bacterial and viral infections indicating impaired NK-cell activities although no detailed information is available so far (66-70).

\section{THE UGLY: STAT3: AVOIDING AUTOIMMUNITY OR THE TARGET FOR NK-CELL THERAPY?}

While cytokines such as IL-12, IL-15, IL-21, and type I IFNs induce STAT3 tyrosine phosphorylation in NK-cells, the most potent activation is achieved by treatment with the immunosuppressive and anti-inflammatory cytokine IL-10 (71). Many tumors harbor constitutively active STAT3 that triggers the release of immunosuppressive cytokines such as IL-10 or TGF- $\beta$. These tumor-derived cytokines further induce a pronounced STAT3 phosphorylation in infiltrating immune cells. There, induced STAT3 activation is considered to impair tumor immune surveillance and allows the tumor to escape immune control $(72,73)$. High levels of STAT3 phosphorylation in the tumor stroma often correlate with loss of intact tumor immune surveillance (74). This effect is of therapeutic interest as STAT3 inhibitors are currently developed to treat patients suffering from cancer of various origin $(75,76)$. There is dual hope in these STAT3-directed therapies; on the one side, they are expected to block STAT3-mediated growth promoting and pro-survival signals in the tumor cells themselves. On the other hand, STAT3 inhibitors directly act on the infiltrating immune cells and might boost their cytotoxic behavior.

There is first evidence that this concept holds true for NK-cells. Studies in mouse models uncovered that STAT3 activation in NK-cells indeed suppresses cytotoxicity. The deletion of STAT3 in NK-cells enhanced cytotoxicity in melanoma and leukemia models $(71,77)$ and resulted in a prolonged survival $(71)$. The absence of STAT3 was paralleled by an increased expression of perforin and granzyme B and the activating receptor DNAM-1. There is conflicting evidence if and how STAT3 also regulates the expression of the activating NKG2D receptor in NK-cells. In human, NK-cells stimulation with IL-10 and IL-21 induces NKG2D expression in a STAT3-dependent manner. Similar results were obtained in a mouse study showing enhanced NKG2D-mediated antitumor responses upon IL-21 treatment $(78,79)$. Against the expectations, Stat $3^{-/-}$NK-cells isolated from Stat $3^{f / f l} \mathrm{Ncr} 1-\mathrm{Cr} \mathrm{C}^{\mathrm{Tg}}$ mice, where deletion of STAT3 is restricted to NKp46 ${ }^{+}$cells, show no changes in NKG2D expression (71). In contrast, NK-cells analyzed from Stat $3^{f l / f}$ VavCre mice showed reduced NKG2D expression (79). The controversy is further heated by a study showing that IL-21 stimulation inhibits NKG2D expression of IL-2-cultured primary human NK-cells (80). Several scenarios 
may explain these conflicting results; one may envision that STAT3 is involved in epigenetic processes that control NKG2D expression and that occur prior to NKp46 expression. In such a scenario, the deletion of STAT3 in a NKp46 $6^{+}$population would be too late in NK-cell development to interfere with NKG2D expression. Alternatively, the regulation of NKG2D expression in NK-cells might require cell extrinsic-cues that depend on STAT3 and are lost in Stat $3^{f / f l}$ VavCre mice upon deletion in the entire hematopoietic system (79).

Of note, STAT3 inhibition in tumors has been shown to enhance immunogenicity even in tumors that do not depend on STAT3 for survival and growth. One of the mechanisms how immunogenicity is increased is the enhanced expression of NKG2D ligands on tumor cells $(81,82)$.

Another consequence of STAT3 deletion in NK-cells is an increased expression level of STAT5 (71). As described below, STAT5 is a potent stimulator of NK-cell survival and cytotoxicity. It remains to be determined how any STAT3-directed therapy will interfere with the delicate balance of STAT3-mediated suppression and STAT5-mediated activation of NK-cell cytotoxicity. This is of particular relevance when employing cytokines that act via both STAT proteins, e.g., IL-15. It is attractive to speculate that IL-15-induced STAT3 activation may serve to counteract the IL-15-STAT5-mediated NK-cell cytotoxicity to prevent autoimmunity. A detailed understanding of the mechanisms governing the repression of NK-cell overshoots is of utmost therapeutic importance. Cancer therapies aim at increasing the potential of killers while avoiding self-destruction.

\section{THE GOOD: STAT4: YOU BETTER HAVE MORE}

STAT4 is a prerequisite for IL-12-mediated cytotoxicity and IFN- $\gamma$ production in murine and human NK-cells $(83,84)$. Additionally, STAT4 has been described to induce T-bet and IL-10 in NK-cells and to be involved in the generation of memory NK-cells after MCMV infection $(83,85,86)$. Direct binding of STAT4 to the perforin promoter has been reported in human NK-cells (87). Besides its potent activation by IL-12 stimulation, high basal levels of STAT4 protein expression have been detected in murine and human NK-cells (61). In contrast to other immune cells, IL-2 treatment activates STAT4 in NK-cells and enhances responses to IL- 12 by upregulating of the $\operatorname{IL12R}(38,84)$. It is attractive to speculate that the constitutively high expression levels of STAT4 represent a "ready-to-go" repertoire that enables NK-cells to immediately react on cytokine exposure. This hypothesis is supported by the fact that NK-cells represent the first line of defense against pathogens-their rapid and efficient activation being a prerequisite. In line, tolerogenic NK-cells have been reported in the context of liver transplantation, where immunosuppression subsequently decreased STAT4 levels and resulting in hyporesponsive NK-cells (88).

Although IL-12 possesses the potential to also activate STAT1 and STAT3, STAT4 appears to be crucial in mediating IL-12induced signaling and IFN- $\gamma$ production. The role of IL-12induced STAT1 and STAT3 activation for IFN- $\gamma$ production is currently unclear. It may represent an evolutionary backup to induce a second wave of IFN- $\gamma$ response. On the other hand, STAT1 and STAT3 may act as feedback loop and prevent successive production. In fact, binding of several STAT molecules to the IFN- $\gamma$ promoter has been reported $(71,89)$.

\section{THE GOOD: STAT5: TEACHES NK-CELLS HOW TO DRIVE}

STAT5 transmits signals downstream of IL-2 and IL-15, and its expression is indispensable for the survival of peripheral NK-cells (90). STAT5 exists of two homologs, STAT5A and STAT5B, that share more than $90 \%$ sequence identity and arose by gene duplication (91). There is evidence that the loss of STAT5B, but not STAT5A reduces NK-cell numbers and impairs cytolytic responses (92). This is mirrored in patients harboring Stat5b deficiencies and suffering from NK-cell lymphopenia, recurrent bacterial and viral infections, several clinical pathologies, and high morbidity $(67,93)$. While the deletion of STAT5B only reduces NK-cell numbers to $50 \%$, the targeted deletion of STAT5A and STAT5B in NK-cells induces apoptosis and leads to a complete loss of peripheral NK-cells (90). These data indicate that both STAT5 isoforms are involved in NK-cell maturation and survival (90). Survival of STAT5-deficient NK-cells can be rescued by the enhanced expression of the anti-apoptotic gene $\mathrm{Bcl}-2$ and allows studying the role of STAT5 for other NK-cell functions. STAT5 is not only regulating NK-cell survival, proliferation, and cytotoxicity but also drives cell maturation (94) by driving the expression of transcription factors involved in NK-cell maturation and survival (94). Besides allowing NK-cell maturation and cytotoxicity, STAT5 suppresses the tumor-promoting potential of NK-cells (94). Similar to myeloid cells, NK-cells have the potential to support tumor growth by secreting VEGF-A $(94,95)$. VEGF-A expression and thus tumor promotion is suppressed by STAT5 with STAT5B being the relevant isoform (94). There is accumulating evidence for the existence of VEGF-A secreting tumor infiltrating NK-cells in patients suffering from small lung cell cancer, breast, and colon tumors $(96,97)$. These tumor-promoting NK-cells are immature (CD56 $6^{\text {bright }}$ ), and their presence has been correlated to poor disease prognosis in several studies (98-100). Therefore, it is attractive to speculate that IL-2- and IL-15-mediated STAT5 activation in cancer patients does not only activate NK-cell cytotoxicity but also reverts pro-angiogenic effects. Decidual NK-cells have been the first NK-cells reported to produce VEGF to promote trophoblast invasion and remodeling of spiral arteries (101-103). Uterine NK-cells are poorly cytotoxic with a particular cytokine profile (101). It remains to be elucidated whether STAT5 is also involved in VEGF-A production in the decidua. A suppressive cytokine milieu such as TGF- $\beta$ in the uterus or hypoxic conditions might dampen STAT5 signaling and represent a prerequisite for VEGF-A transcription. Evolution brought two types of NK-cells into light: besides being effective killers NK-cells have acquired to adapt to immunosuppressive cytokines and to switch to a tolerogenic but pro-angiogenic behavior. 


\section{THE BAD: STAT6: STILL SOME MISSING BRICKS}

Activation of STAT6 has been reported to drive IL-5 and IL-13 production in cultured NK-cells and to limit cytotoxic responses (104). In line, studies with Stat6 ${ }^{-/-}$mice showed increased viral resistance and higher cytolytic activity of NK-cells in the absence of STAT6 (105). However, a positive correlation of STAT6 expression and IFN- $\gamma$ production was reported after costimulating murine NK-cells with IL-4 and IL-2 (106). Further studies need to explore whether a STAT6 blockade would be a potential therapeutic option to enhance responses in human NK-cells.

\section{CONCLUSION}

The JAK-STAT pathway is evolutionary highly conserved; thus, the human situation nicely matches the findings in experimental animal models. In that line, many insights that we gained from murine NK-cells can be translated to human NK-cells. Figure 1 summarizes our current knowledge on the role of STATs in NK-cell functions. In general, STAT1, STAT4, and STAT5 stimulate NK-cell maturation and cytotoxicity, whereas STAT3 and STAT6 negatively impact on NK-cell activity. It is attractive to speculate that the suppressive role of STAT3 and STAT6 is important to prevent NK-cell overshoots and autoimmunity. STAT5 is the only STAT family member that is indispensable for NK-cells since it governs survival and growth in addition to cytotoxicity and maturation. It may thus be seen as NK-cell master regulator.

As shown for macrophages NK-cells not only inhibit but also promote tumor formation, e.g., by producing VEGF-A. So far, STAT5 has been shown to prevent NK-cell-mediated tumor promotion by suppressing VEGF-A. However, it is unclear if and how other family members contribute to the switch from tumor suppression to tumor progression. Another layer of complexity is added by the fact that STATs rarely act alone but are embedded in a network of signaling events depending on the microenvironment and stimuli present. Signal integration is required to determine outcomes; at its lowest level integration of activity arising from various STAT family members is needed as even a single cytokine can activate multiple STATs (listed in Table 1). Some cytokines activate STAT family members with opposing functions such as IL-12 or type I IFNs. Further research will have

\section{REFERENCES}

1. Caligiuri MA. Human natural killer cells. Blood (2008) 112:461-9. doi:10.1182/blood-2007-09-077438

2. Cooper MA, Fehniger TA, Caligiuri MA. The biology of human natural killer-cell subsets. Trends Immunol (2001) 22:633-40. doi:10.1016/S14714906(01)02060-9

3. Waldhauer I, Steinle A. NK-cells and cancer immunosurveillance. Oncogene (2008) 27:5932-43. doi:10.1038/onc.2008.267

4. Vermijlen D, Luo D, Froelich CJ, Medema JP, Kummer JA, Willems E, et al. Hepatic natural killer cells exclusively kill splenic/blood natural killer-resistant tumor cells by the perforin/granzyme pathway. J Leukoc Biol (2002) 72:668-76.

5. Giezeman-Smits KM, Gorter A, van Vlierberghe RL, Giezeman-Smits KM, v Eendenburg JD, Eggermont AM, et al. The regulatory role of CD45 on rat NK-cells in target cell lysis. J Immunol Ref J Immunol UCSF Libr (2016) 163:71-6.

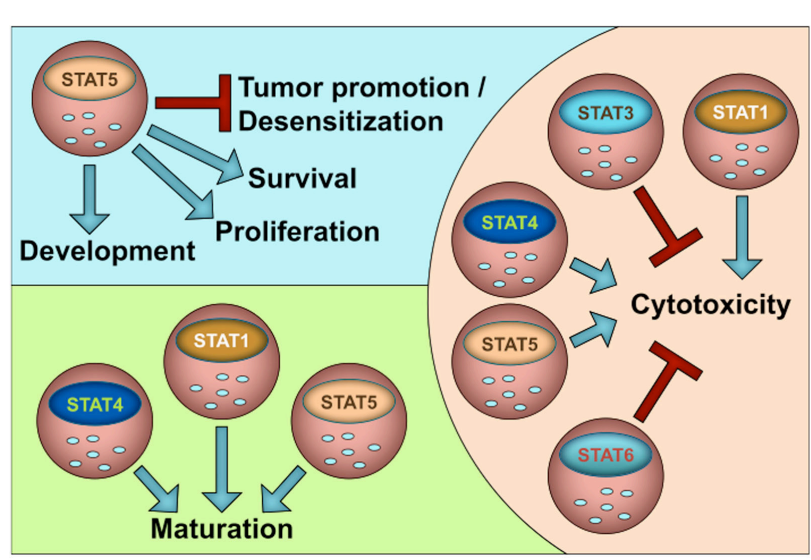

FIGURE 1 | The role of STATs for NK cell homeostasis and function.

to link NK activity and biological outcomes to cytokine-induced STAT activation and their synergic and/or antagonistic roles. The evolving field of systems biology may be of help to address these issues and/or to even predict the complex biologically and medically relevant questions in vivo at high pace to optimize current cancer therapies.

\section{AUTHOR CONTRIBUTIONS}

All authors listed have made substantial, direct, and intellectual contribution to the work and approved it for publication.

\section{ACKNOWLEDGMENTS}

The authors thank the entire JAK-STAT community in Vienna for the many discussions on JAK-STAT signaling in NK-cells. They are grateful to Peter Martinek for his help with the graphical illustration and to Andrea Hölbl-Kovacic for detailed corrections and editing the manuscript.

\section{FUNDING}

The authors were supported by the $\mathrm{PhD}$ program "Inflammation and Immunity” FWF W1212 and the grant FWF P28571-B21.

6. Putz EM, Gotthardt D, Hoermann G, Csiszar A, Wirth S, Berger A, et al. CDK8-mediated STAT1-S727 phosphorylation restrains NK-cell cytotoxicity and tumor surveillance. Cell Rep (2013) 4(3):437-44. doi:10.1016/j. celrep.2013.07.012

7. Bottos A, Gotthardt D, Gill JW, Gattelli A, Frei A, Tzankov A, et al. Decreased NK-cell tumour immunosurveillance consequent to JAK inhibition enhances metastasis in breast cancer models. Nat Commun (2016) 7:12258. doi: $10.1038 /$ ncomms 12258

8. Langers I, Renoux VM, Thiry M, Delvenne P, Jacobs N. Natural killer cells: role in local tumor growth and metastasis. Biologics (2012) 6:73-82. doi:10.2147/BTT.S23976

9. Cichocki F, Miller JS, Anderson SK, Bryceson YT. Epigenetic regulation of NK-cell differentiation and effector functions. Front Immunol (2013) 4:55. doi:10.3389/fimmu.2013.00055

10. Orr MT, Lanier LL. Natural killer cell education and tolerance. Cell (2010) 142:847-56. doi:10.1016/j.cell.2010.08.031 
11. Lanier LL. Up on the tightrope: natural killer cell activation and inhibition. Nat Immunol (2008) 9:495-502. doi:10.1038/ni1581

12. Watzl C, Urlaub D, Fasbender F, Claus M. Natural killer cell regulation beyond the receptors. F1000Prime Rep (2014) 6:87. doi:10.12703/P6-87

13. Raulet DH, Vance RE. Self-tolerance of natural killer cells. Nat Rev Immunol (2006) 6:520-31. doi:10.1038/nri1863

14. Yokoyama WM, Kim S. How do natural killer cells find self to achieve tolerance? Immunity (2006) 24:249-57. doi:10.1016/j.immuni.2006.03.006

15. Bryceson YT, March ME, Ljunggren H-G, Long EO. Activation, coactivation, and costimulation of resting human natural killer cells. Immunol Rev (2006) 214:73-91. doi:10.1111/j.1600-065X.2006.00457.x

16. Smyth MJ, Cretney E, Kelly JM, Westwood JA, Street SE, Yagita H, et al. Activation of NK-cell cytotoxicity. Mol Immunol (2005) 42:501-10. doi:10.1016/j.molimm.2004.07.034

17. Lucas M, Schachterle W, Oberle K, Aichele P, Diefenbach A. Dendritic cells prime natural killer cells by trans-presenting interleukin 15. Immunity (2007) 26:503-17. doi:10.1016/j.immuni.2007.03.006

18. Kerdiles Y, Ugolini S, Vivier E. T cell regulation of natural killer cells. J Exp Med (2013) 210:1065-8. doi:10.1084/jem.20130960

19. Ralainirina N, Poli A, Michel T, Poos L, Andrès E, Hentges F, et al. Control of NK-cell functions by CD4+CD25+ regulatory T cells. J Leukoc Biol (2007) 81:144-53. doi:10.1189/jlb.0606409

20. Cheng M, Chen Y, Xiao W, Sun R, Tian Z. NK-cell-based immunotherapy for malignant diseases. Cell Mol Immunol (2013) 10:230-52. doi:10.1038/ cmi. 2013.10

21. Naganuma H, Sasaki A, Satoh E, Nagasaka M, Nakano S, Isoe S, et al. Transforming growth factor-beta inhibits interferon-gamma secretion by lymphokine-activated killer cells stimulated with tumor cells. Neurol Med Chir (Tokyo) (1996) 36:789-95. doi:10.2176/nmc.36.789

22. Mittal D, Young A, Stannard K, Yong M, Teng MWL, Allard B, et al. Antimetastatic effects of blocking PD-1 and the adenosine A2A receptor. Cancer Res (2014) 74:3652-8. doi:10.1158/0008-5472.CAN-14-0957

23. Imada K, Leonard WJ. The Jak-STAT pathway. Mol Immunol (2000) 37:1-11. doi:10.1016/S0161-5890(00)00018-3

24. Yu H, Jove R. The STATs of cancer - new molecular targets come of age. Nat Rev Cancer (2004) 4:97-105. doi:10.1038/nrc1275

25. Springuel L, Renauld J-C, Knoops L. JAK kinase targeting in hematologic malignancies: a sinuous pathway from identification of genetic alterations towards clinical indications. Haematologica (2015) 100:1240-53. doi:10.3324/ haematol.2015.132142

26. Yu H, Pardoll D, Jove R. STATs in cancer inflammation and immunity: a leading role for STAT3. Nat Rev Cancer (2009) 9:798-809. doi:10.1038/nrc2734

27. Murray PJ. The JAK-STAT signaling pathway: input and output integration. J Immunol (2007) 178:2623-9. doi:10.4049/jimmunol.178.5.2623

28. Li WX. Canonical and non-canonical JAK-STAT signaling. Trends Cell Biol (2008) 18:545-51. doi:10.1016/j.tcb.2008.08.008

29. Kallal LE, Biron CA. Changing partners at the dance: variations in STAT concentrations for shaping cytokine function and immune responses to viral infections. JAKSTAT (2013) 2:e23504. doi:10.4161/jkst.23504

30. Liu Z, Yang L, Cui Y, Wang X, Guo C, Huang Z, et al. IL-21 enhances NK-cell activation and cytolytic activity and induces Th17 cell differentiation in inflammatory bowel disease. Inflamm Bowel Dis (2009) 15:1133-44. doi:10.1002/ibd.20923

31. Brady J, Hayakawa Y, Smyth MJ, Nutt SL. IL-21 induces the functional maturation of murine NK-cells. J Immunol (2004) 172:2048-58. doi:10.4049/ jimmunol.172.4.2048

32. Mocellin S, Panelli M, Wang E, Rossi CR, Pilati P, Nitti D, et al. IL-10 stimulatory effects on human NK-cells explored by gene profile analysis. Genes Immun (2004) 5:621-30. doi:10.1038/sj.gene.6364135

33. Michaud A, Dardari R, Charrier E, Cordeiro P, Herblot S, Duval M. IL-7 enhances survival of human CD56bright NK-cells. JImmunother (2010) 33:382-90. doi:10.1097/CJI.0b013e3181cd872d

34. Wendt K, Wilk E, Buyny S, Schmidt RE, Jacobs R. Interleukin-21 differentially affects human natural killer cell subsets. Immunology (2007) 122:486-95. doi:10.1111/j.1365-2567.2007.02675.x

35. D’Andrea A, Aste-Amezaga M, Valiante NM, Ma X, Kubin M, Trinchieri G. Interleukin 10 (IL-10) inhibits human lymphocyte interferon gammaproduction by suppressing natural killer cell stimulatory factor/IL-12 synthesis in accessory cells. JExp Med (1993) 178:1041-8. doi:10.1084/ jem.178.3.1041

36. Pillet A-H, Bugault F, Thèze J, Chakrabarti LA, Rose T. A programmed switch from IL-15- to IL-2-dependent activation in human NK-cells. J Immunol (2009) 182:6267-77. doi:10.4049/jimmunol.0801933

37. DeBlaker-Hohe DF, Yamauchi A, Yu CR, Horvath-Arcidiacono JA, Bloom ET. IL-12 synergizes with IL-2 to induce lymphokine-activated cytotoxicity and perforin and granzyme gene expression in fresh human NK-cells. Cell Immunol (1995) 165:33-43. doi:10.1006/cimm.1995.1184

38. Wang KS, Ritz J, Frank DA. IL-2 induces STAT4 activation in primary NK-cells and NK-cell lines, but not in T cells. JImmunol (1999) 162: 299-304.

39. Carson WE, Giri JG, Lindemann MJ, Linett ML, Ahdieh M, Paxton R, et al. Interleukin (IL) 15 is a novel cytokine that activates human natural killer cells via components of the IL-2 receptor. J Exp Med (1994) 180:1395-403. doi:10.1084/jem.180.4.1395

40. Matikainen S, Paananen A, Miettinen M, Kurimoto M, Timonen T, Julkunen I, et al. IFN-alpha and IL-18 synergistically enhance IFN-gamma production in human NK-cells: differential regulation of Stat 4 activation and IFN-gamma gene expression by IFN-alpha and IL-12. Eur J Immunol (2001) 31:2236-45. doi:10.1002/1521-4141(200107)31:7<2236::AID-IMMU2236>3.3.CO;2-7

41. Mizutani T, Neugebauer N, Putz EM, Moritz N, Simma O, Zebedin-Brandl E, et al. Conditional IFNAR1 ablation reveals distinct requirements of type I IFN signaling for NK-cell maturation and tumor surveillance. Oncoimmunology (2012) 1:1027-37. doi:10.4161/onci.21284

42. Ziblat A, Domaica CI, Spallanzani RG, Iraolagoitia XLR, Rossi LE, Avila DE, et al. IL-27 stimulates human NK-cell effector functions and primes NK-cells for IL-18 responsiveness. Eur J Immunol (2015) 45:192-202. doi:10.1002/ eji.201444699

43. Matsui M, Kishida T, Nakano H, Yoshimoto K, Shin-Ya M, Shimada T, et al. Interleukin-27 activates natural killer cells and suppresses NK-resistant head and neck squamous cell carcinoma through inducing antibody-dependent cellular cytotoxicity. Cancer Res (2009) 69:2523-30. doi:10.1158/0008-5472. CAN-08-2793

44. Laroni A, Gandhi R, Beynon V, Weiner HL. IL-27 imparts immunoregulatory function to human NK-cell subsets. PLoS One (2011) 6:e26173. doi:10.1371/ journal.pone. 0026173

45. Vosshenrich CAJ, Ranson T, Samson SI, Corcuff E, Colucci F, Rosmaraki EE, et al. Roles for common cytokine receptor gamma-chain-dependent cytokines in the generation, differentiation, and maturation of NK-cell precursors and peripheral NK-cells in vivo. J Immunol (2005) 174:1213-21. doi:10.4049/ jimmunol.174.3.1213

46. Stark GR, Darnell JE. The JAK-STAT pathway at twenty. Immunity (2012) 36:503-14. doi:10.1016/j.immuni.2012.03.013

47. Schönberg K, Rudolph J, Vonnahme M, Parampalli S, Cornez I, Hejazi M, et al. JAK inhibition impairs NK-cell function. Cancer Res (2015) 75(11):2187-99. doi:10.1158/0008-5472.CAN-14-3198

48. Park SY, Saijo K, Takahashi T, Osawa M, Arase H, Hirayama N, et al. Developmental defects of lymphoid cells in Jak3 kinase-deficient mice. Immunity (1995) 3:771-82. doi:10.1016/1074-7613(95)90066-7

49. Nosaka T, van Deursen JM, Tripp RA, Thierfelder WE, Witthuhn BA, McMickle AP, et al. Defective lymphoid development in mice lacking Jak3. Science (1995) 270:800-2. doi:10.1126/science.270.5237.800

50. Roberts JL, Lengi A, Brown SM, Chen M, Zhou Y-J, O'Shea JJ, et al. Janus kinase 3 (JAK3) deficiency: clinical, immunologic, and molecular analyses of 10 patients and outcomes of stem cell transplantation. Blood (2004) 103:2009-18. doi:10.1182/blood-2003-06-2104

51. Neubauer H, Cumano A, Muller M, Wu H, Huffstadt U, Pfeffer K. Jak2 deficiency defines an essential developmental checkpoint in definitive hematopoiesis. Cell (1998) 93:397-409. doi:10.1016/S0092-8674(00) 81168-X

52. Rodig SJ, Meraz MA, White JM, Lampe PA, Riley JK, Arthur CD, et al. Disruption of the Jak1 gene demonstrates obligatory and nonredundant roles of the Jaks in cytokine-induced biologic responses. Cell (1998) 93:373-83. doi:10.1016/S0092-8674(00)81166-6

53. Delconte RB, Kolesnik TB, Dagley LF, Rautela J, Shi W, Putz EM, et al. CIS is a potent checkpoint in NK-cell-mediated tumor immunity. Nat Immunol (2016) 17:816-24. doi:10.1038/ni.3470 
54. Ghoreschi K, Laurence A, O'Shea JJ. Janus kinases in immune cell signaling. Immunol Rev (2009) 228:273-87. doi:10.1111/j.1600-065X.2008.00754.x

55. Stoiber D, Kovacic B, Schuster C, Schellack C, Karaghiosoff M, Kreibich R, et al. TYK2 is a key regulator of the surveillance of B lymphoid tumors. J Clin Invest (2004) 114:1650-8. doi:10.1172/JCI22315

56. Prchal-Murphy M, Witalisz-Siepracka A, Bednarik KT, Putz EM, Gotthardt $\mathrm{D}$, Meissl K, et al. In vivo tumor surveillance by NK-cells requires TYK2 but not TYK2 kinase activity. Oncoimmunology (2015) 4:e1047579. doi:10.1080/ 2162402X.2015.1047579

57. Schleicher U, Mattner J, Blos M, Schindler H, Rollinghoff M, Karaghiosoff $\mathrm{M}$, et al. Control of Leishmania major in the absence of Tyk2 kinase. Eur J Immunol (2004) 34:519-29. doi:10.1002/eji.200324465

58. Shimoda K, Tsutsui H, Aoki K, Kato K, Matsuda T, Numata A, et al. Partial impairment of interleukin-12 (IL-12) and IL-18 signaling in Tyk2-deficient mice. Blood (2002) 99:2094-9. doi:10.1182/blood.V99.6.2094

59. Kreins AY, Ciancanelli MJ, Okada S, Kong X-F, Ramírez-Alejo N, Kilic SS, et al. Human TYK2 deficiency: mycobacterial and viral infections without hyper-IgE syndrome. J Exp Med (2015) 212:1641-62. doi:10.1084/ jem.20140280

60. Au-Yeung N, Mandhana R, Horvath CM. Transcriptional regulation by STAT1 and STAT2 in the interferon JAK-STAT pathway. JAKSTAT (2013) 2:e23931. doi:10.4161/jkst.23931

61. Miyagi T, Gil MP, Wang X, Louten J, Chu WM, Biron CA. High basal STAT4 balanced by STAT1 induction to control type 1 interferon effects in natural killer cells. J Exp Med (2007) 204:2383-96. doi:10.1084/jem. 20070401

62. Liang S, Wei H, Sun R, Tian Z. IFNalpha regulates NK-cell cytotoxicity through STAT1 pathway. Cytokine (2003) 23:190-9. doi:10.1016/ S1043-4666(03)00226-6

63. Lesinski GB, Anghelina M, Zimmerer J, Bakalakos T, Badgwell B, Parihar R, et al. The antitumor effects of IFN-alpha are abrogated in a STAT1-deficient mouse. J Clin Invest (2003) 112:170-80. doi:10.1172/JCI16603

64. Robbins SH, Tessmer MS, Van Kaer L, Brossay L. Direct effects of T-bet and MHC class I expression, but not STAT1, on peripheral NK-cell maturation. Eur J Immunol (2005) 35:757-65. doi:10.1002/eji.200425797

65. Putz EM, Majoros A, Gotthardt D, Prchal-Murphy M, Zebedin-Brandl EM, Fux DA, et al. Novel non-canonical role of STAT1 in natural killer cell cytotoxicity. Oncoimmunology (2016) 5(9):e1186314. doi:10.1080/2162402X. 2016.1186314

66. Vairo D, Tassone L, Tabellini G, Tamassia N, Gasperini S, Bazzoni F, et al. Severe impairment of IFN- $\gamma$ and IFN- $\alpha$ responses in cells of a patient with a novel STAT1 splicing mutation. Blood (2011) 118:1806-17. doi:10.1182/ blood-2011-01-330571

67. Jouanguy E, Gineau L, Cottineau J, Béziat V, Vivier E, Casanova J-L. Inborn errors of the development of human natural killer cells. Curr Opin Allergy Clin Immunol (2013) 13:589-95. doi:10.1097/ACI.0000000000000011

68. Dupuis S, Jouanguy E, Al-Hajjar S, Fieschi C, Al-Mohsen IZ, Al-Jumaah $\mathrm{S}$, et al. Impaired response to interferon-alpha/beta and lethal viral disease in human STAT1 deficiency. Nat Genet (2003) 33:388-91. doi:10.1038/ ng1097

69. Chapgier A, Kong X-F, Boisson-Dupuis S, Jouanguy E, Averbuch D, Feinberg $\mathrm{J}$, et al. A partial form of recessive STAT1 deficiency in humans. J Clin Invest (2009) 119:1502-14. doi:10.1172/JCI37083

70. Boisson-Dupuis S, Kong X-F, Okada S, Cypowyj S, Puel A, Abel L, et al. Inborn errors of human STAT1: allelic heterogeneity governs the diversity of immunological and infectious phenotypes. Curr Opin Immunol (2012) 24:364-78. doi:10.1016/j.coi.2012.04.011

71. Gotthardt D, Putz EM, Straka E, Kudweis P, Biaggio M, Poli V, et al. Loss of STAT3 in murine NK-cells enhances NK-cell-dependent tumor surveillance. Blood (2014) 124:2370-9. doi:10.1182/blood-2014-03-564450

72. Kortylewski M, Yu H. Role of Stat3 in suppressing anti-tumor immunity. Curr Opin Immunol (2008) 20:228-33. doi:10.1016/j.coi.2008.03.010

73. Cacalano NA. Regulation of natural killer cell function by STAT3. Front Immunol (2016) 7:128. doi:10.3389/fimmu.2016.00128

74. Yu H, Kortylewski M, Pardoll D. Crosstalk between cancer and immune cells: role of STAT3 in the tumour microenvironment. Nat Rev Immunol (2007) 7:41-51. doi:10.1038/nri1995

75. Yue P, Turkson J. Targeting STAT3 in cancer: how successful are we? Expert Opin Investig Drugs (2009) 18:45-56. doi:10.1517/13543780802565791
76. Siveen KS, Sikka S, Surana R, Dai X, Zhang J, Kumar AP, et al. Targeting the STAT3 signaling pathway in cancer: role of synthetic and natural inhibitors. Biochim Biophys Acta (2014) 1845:136-54. doi:10.1016/j.bbcan. 2013.12.005

77. Kortylewski M, Kujawski M, Wang T, Wei S, Zhang S, Pilon-Thomas S, et al. Inhibiting Stat3 signaling in the hematopoietic system elicits multicomponent antitumor immunity. Nat Med (2005) 11:1314-21. doi:10.1038/ nm1325

78. Takaki R, Hayakawa Y, Nelson A, Sivakumar PV, Hughes S, Smyth MJ, et al. IL-21 enhances tumor rejection through a NKG2D-dependent mechanism. J Immunol (2005) 175:2167-73. doi:10.4049/jimmunol.175.4.2167

79. Zhu S, Phatarpekar PV, Denman CJ, Senyukov VV, Somanchi SS, NguyenJackson HT, et al. Transcription of the activating receptor NKG2D in natural killer cells is regulated by STAT3 tyrosine phosphorylation. Blood (2014) 124:403-11. doi:10.1182/blood-2013-05-499707

80. Burgess SJ, Marusina AI, Pathmanathan I, Borrego F, Coligan JE. IL-21 down-regulates NKG2D/DAP10 expression on human NK and CD8+ T cells. J Immunol (2006) 176:1490-7. doi:10.4049/jimmunol.176.3.1490

81. Bedel R, Thiery-Vuillemin A, Grandclement C, Balland J, Remy-Martin J-P, Kantelip B, et al. Novel role for STAT3 in transcriptional regulation of NK immune cell targeting receptor MICA on cancer cells. Cancer Res (2011) 71:1615-26. doi:10.1158/0008-5472.CAN-09-4540

82. Fionda C, Malgarini G, Soriani A, Zingoni A, Cecere F, Iannitto ML, et al. Inhibition of glycogen synthase kinase-3 increases NKG2D ligand MICA expression and sensitivity to NK-cell-mediated cytotoxicity in multiple myeloma cells: role of STAT3. J Immunol (2013) 190:6662-72. doi:10.4049/ jimmunol.1201426

83. Townsend MJ, Weinmann AS, Matsuda JL, Salomon R, Farnham PJ, Biron $\mathrm{CA}$, et al. T-bet regulates the terminal maturation and homeostasis of NK and Valpha14i NKT cells. Immunity (2004) 20:477-94. doi:10.1016/ S1074-7613(04)00076-7

84. Wang KS, Frank DA, Ritz J. Interleukin-2 enhances the response of natural killer cells to interleukin-12 through up-regulation of the interleukin-12 receptor and STAT4. Blood (2000) 95:3183-90.

85. Sun JC, Madera S, Bezman NA, Beilke JN, Kaplan MH, Lanier LL. Proinflammatory cytokine signaling required for the generation of natural killer cell memory. J Exp Med (2012) 209:947-54. doi:10.1084/jem. 20111760

86. Grant LR, Yao Z-J, Hedrich CM, Wang F, Moorthy A, Wilson K, et al. Stat4dependent, T-bet-independent regulation of IL-10 in NK-cells. Genes Immun (2008) 9:316-27. doi:10.1038/gene.2008.20

87. Yamamoto K, Shibata F, Miyasaka N, Miura O. The human perforin gene is a direct target of STAT4 activated by IL-12 in NK-cells. Biochem Biophys Res Commun (2002) 297:1245-52. doi:10.1016/S0006-291X(02)02378-1

88. Jamil KM, Hydes TJ, Cheent KS, Cassidy SA, Traherne JA, Jayaraman J, et al. STAT4-associated natural killer cell tolerance following liver transplantation. Gut (2016). doi:10.1136/gutjnl-2015-309395

89. Xu X, Sun YL, Hoey T. Cooperative DNA binding and sequence-selective recognition conferred by the STAT amino-terminal domain. Science (1996) 273:794-7. doi:10.1126/science.273.5276.794

90. Eckelhart E, Warsch W, Zebedin E, Simma O, Stoiber D, Kolbe T, et al. A novel Ncr1-Cre mouse reveals the essential role of STAT5 for NK-cell survival and development. Blood (2011) 117:1565-73. doi:10.1182/blood2010-06-291633

91. Berger A, Sexl V, Valent P, Moriggl R. Inhibition of STAT5: a therapeutic option in BCR-ABL1-driven leukemia. Oncotarget (2014) 5:9564-76. doi:10.18632/oncotarget. 2465

92. Imada K, Bloom ET, Nakajima H, Horvath-Arcidiacono JA, Udy GB, Davey HW, et al. Stat5b is essential for natural killer cell-mediated proliferation and cytolytic activity. J Exp Med (1998) 188:2067-74. doi:10.1084/ jem.188.11.2067

93. Bezrodnik L, Di Giovanni D, Caldirola MS, Azcoiti ME, Torgerson T, Gaillard MI. Long-term follow-up of STAT5B deficiency in three Argentinian patients: clinical and immunological features. JClin Immunol (2015) 35:264-72. doi:10.1007/s10875-015-0145-5

94. Gotthardt D, Putz EM, Grundschober E, Prchal-Murphy M, Straka E, Kudweis P, et al. STAT5 is a key regulator in NK-cells and acts as a molecular switch from tumor surveillance to tumor promotion. Cancer Discov (2016) 6:414-29. doi:10.1158/2159-8290.CD-15-0732 
95. Coffelt SB, Hughes R, Lewis CE. Tumor-associated macrophages: effectors of angiogenesis and tumor progression. Biochim Biophys Acta (2009) 1796:11-8. doi:10.1016/j.bbcan.2009.02.004

96. Levi I, Amsalem H, Nissan A, Darash-Yahana M, Peretz T, Mandelboim $\mathrm{O}$, et al. Characterization of tumor infiltrating natural killer cell subset. Oncotarget (2015) 6:13835-43. doi:10.18632/oncotarget.3453

97. Bruno A, Focaccetti C, Pagani A, Imperatori AS, Spagnoletti M, Rotolo N, et al. The proangiogenic phenotype of natural killer cells in patients with non-small cell lung cancer. Neoplasia (2013) 15:133-42. doi:10.1593/neo. 121758

98. Mamessier E, Sylvain A, Thibult ML, Houvenaeghel G, Jacquemier J, Castellano R, et al. Human breast cancer cells enhance self tolerance by promoting evasion from NK-cell antitumor immunity. J Clin Invest (2011) 121:3609-22. doi:10.1172/JCI45816

99. Carrega P, Morandi B, Costa R, Frumento G, Forte G, Altavilla G, et al. Natural killer cells infiltrating human nonsmall-cell lung cancer are enriched in CD56brightCD16- cells and display an impaired capability to kill tumor cells. Cancer (2008) 112:863-75. doi:10.1002/cncr.23239

100. Hejazi M, Manser AR, Fröbel J, Kündgen A, Zhao X, Schönberg K, et al. Impaired cytotoxicity associated with defective natural killer cell differentiation in myelodysplastic syndromes. Haematologica (2015) 100:643-52. doi:10.3324/haematol.2014.118679

101. Hanna J, Goldman-Wohl D, Hamani Y, Avraham I, Greenfield C, NatansonYaron S, et al. Decidual NK-cells regulate key developmental processes at the human fetal-maternal interface. Nat Med (2006) 12:1065-74. doi:10.1038/ $\mathrm{nm} 1452$

102. Chakraborty D, Rumi MAK, Konno T, Soares MJ. Natural killer cells direct hemochorial placentation by regulating hypoxia-inducible factor dependent trophoblast lineage decisions. Proc Natl Acad Sci US A (2011) 108:16295-300. doi:10.1073/pnas.1109478108

103. Fraser R, Whitley GS, Johnstone AP, Host AJ, Sebire NJ, Thilaganathan B, et al. Impaired decidual natural killer cell regulation of vascular remodelling in early human pregnancies with high uterine artery resistance. J Pathol (2012) 228:322-32. doi:10.1002/path.4057

104. Katsumoto T, Kimura M, Yamashita M, Hosokawa H, Hashimoto K, Hasegawa A, et al. STAT6-dependent differentiation and production of IL-5 and IL-13 in murine NK2 cells. J Immunol (2004) 173:4967-75. doi:10.4049/ jimmunol.173.8.4967

105. Mahalingam S, Karupiah G, Takeda K, Akira S, Matthaei KI, Foster PS. Enhanced resistance in STAT6-deficient mice to infection with ectromelia virus. Proc Natl Acad Sci US A (2001) 98:6812-7. doi:10.1073/pnas.111151098

106. Bream JH, Curiel RE, Yu C-R, Egwuagu CE, Grusby MJ, Aune TM, et al. IL-4 synergistically enhances both IL-2- and IL-12-induced IFN-gamma expression in murine NK-cells. Blood (2003) 102:207-14. doi:10.1182/ blood-2002-08-2602

Conflict of Interest Statement: The authors declare that the research was conducted in the absence of any commercial or financial relationships that could be construed as a potential conflict of interest.

Copyright (C) 2017 Gotthardt and Sexl. This is an open-access article distributed under the terms of the Creative Commons Attribution License (CC BY). The use, distribution or reproduction in other forums is permitted, provided the original author(s) or licensor are credited and that the original publication in this journal is cited, in accordance with accepted academic practice. No use, distribution or reproduction is permitted which does not comply with these terms. 